\title{
Balanced score card for cluster of building materials scrap recycling in Voronezh
}

\author{
Igor Potekhi, ${ }^{1, *}$ \\ ${ }^{1}$ Voronezh State Technical University, Moskovskiy prosp., 14, 394000, Voronezh, Voronezhskaya \\ obl., Russia
}

\begin{abstract}
In this article is described an effort to develop a new system of management and economy of building materials scrap recycling cluster. For this task is used conception "Management by Objective" by American legend Peter Drucker. Thus cluster participants have divergent purposes, but have common purpose, the present conception match the most for develop business strategy of uniting companies in this cluster. As result, it was developed a "Balanced Scorecard" for the cluster. This "Balanced Scorecard" take into account technological features of companies in cluster and developed common purpose system. In base of system structure of indicators there is exist model of cluster. This model can show capacity, output flows and throughput capacity of participants. During develop a system of cluster's purposes it were learned priorities balance of economy efficiency and natural resource management. There are shown calculation of costs of reuse building recycled materials, located on solid waste landfill. Developed strategic system of purpose of cluster activity allows to get economical benefit all participants and for citizens to save environment from nature disaster.
\end{abstract}

\section{Introduction}

By development and setup purposes of cluster's building materials scrap recycling it is advisable to use strategic analysis and management tools such as "Balanced Scorecard" and "Management by Objectives". These strategic analysis and management tools were chosen because cluster is multi-participant with different purposes system. Beside of this obstacle it is possible to determine common purpose, and approaching needed economic results. At the second, "Managing by Objectives" foresee that participants orient not only on process, but to final common purpose. Orientation on objective allows to concentrate efforts and solve conflicts positively. "Managing by Objectives" - process of purposes consideration in corporation such a top-management and staff share and understand meaning of purposes. This term was opened and promoted worldwide by Peter Drucker in 1954 in his book "The Practice of Management" [1].

"Balanced score card" - tool of strategic management for productivity and it is report tool, which helps to managers to understood staff productivity and consequences of execution or non-execution of corporate tasks. This tool is fitted with special methods of automation

\footnotetext{
*Corresponding author: potekhin_300587@mail.ru
} 
and projection. Company develop "Key Performance Indicators" (abbr. KPI) system for own strategy . Main part these system is used to explore efficiency of administrative and management staff. System of KPI could be divide on overdue and advance. To overdue belongs financial indicators. Financial indicators demonstrate link with owners needs and corporation's possibility of cash flow generation, however out of their character, can't show current efficiency and each activities of company. Operative (advance) indicators show the current activity of departments and company. Advance indicators answer - which cash flow should be in future and which quality should have processes and products to satisfy customer. KPI is a part of Balanced Scorecard system, in which settled cause-effect relations between purposes and indicators to see laws and depended factors in business [2, 3].

In the table 1 are shown characteristics of companies' activity in different sectors of process "demolition-recycling-reuse in new house construction". In the table 1 is shown business structure, consists of 3 components: supply a building materials scrap, scrap recycling, sell recycled materials. For each component are defined activities and problems. Supply problems are absence of landing places for building scrap and absence of information about location and capacity of this places. Recycling problems are absence of heavy loading machines and manipulators to manage heavy masses of scrap and recycled materials. In sales of recycled material the main problem is absence of trust in quality of this materials between potential customers and problems of reuse this materials in industrial sector of building structures manufacturing $[4,5,6]$.

Table 1. Characteristic of business structure devoted to construction low-rise buildings made from reused demolished buildings materials.

\begin{tabular}{|c|c|}
\hline Business structure & Description of structure's functions \\
\hline $\begin{array}{l}\text { Supply of building } \\
\text { materials scrap }\end{array}$ & $\begin{array}{l}\text { Activity 1: building demolition } \\
\text { Activity 2: collection a materials out from building demolition } \\
\text { Problem 1: landing, information about geographical location } \\
\text { Problem 2: legitimacy of purchasing building materials scrap }\end{array}$ \\
\hline $\begin{array}{l}\text { Recycling of building } \\
\text { materials scrap to re- } \\
\text { useable materials }\end{array}$ & $\begin{array}{l}\text { Activity 1: sorting } \\
\text { Activity 2: warehousing } \\
\text { Activity 3: small repair } \\
\text { Activity 4: cleaning from contaminations } \\
\text { Problem 1: licensing of operation with materials scrap } \\
\text { Problem 2: absence of technologies of refining building scrap materials. } \\
\text { Need a large staff, heavy equipment and squares of warehousing }\end{array}$ \\
\hline $\begin{array}{l}\text { Construct and sell } \\
\text { new houses, made } \\
\text { from re-useable } \\
\text { materials }\end{array}$ & $\begin{array}{l}\text { Activity 1: new low-rise house or new facility made from reusable } \\
\text { materials } \\
\text { Activity 2: sale reusable building materials } \\
\text { Problem 1: absence of trust and information from people about reliability } \\
\text { and strength of reusable materials and houses from these materials }\end{array}$ \\
\hline
\end{tabular}

In table 2 is presented a structure of reviewed in table 1 companies' structure and their purposes. It is need to ensure in purposes divergence. Structure consists of 4 participants supplier of materials from demolished houses, recycler of materials, builder of new houses out form reusable materials and non-production participants. In this table is shown common purposes and tasks for whole structure. Exploring a Table 2, we can make a conclusion, that beside of participants interests difference, there are common purposes, which they can achieve only in cooperation. But achieving those purpose ask to solute some tasks, which need strong science, technological and organization skills $[13,14,15,16,17,18]$.

In the Table 3 is presented system of Key Performance Indicators (abbr. KPI) for the cluster, which unite companies with different kind of activities. It needs to prove a links of KPI of each participant between their and with common purpose. Balancing KPI have to be done for each participant and for cluster. For example, for demolition works contractor his 
KPI for cost of utilization in legitimize landfill and to non-legitimize landfill have to be non equal. Ration between KPI Demolisher and Recycler have to relation as dependent parameters. KPI of cluster participant and whole cluster could be not related analytically, because for one it is limit, for cluster it is final results

Table 2. Participants' structure in the building materials scrap recycling cluster.

\begin{tabular}{|c|c|c|c|}
\hline $\begin{array}{l}\text { Supplier } \\
\text { of building scrap from } \\
\text { demolition site }\end{array}$ & $\begin{array}{l}\text { Recycler } \\
\text { of building scrap to } \\
\text { reusable building } \\
\text { materials }\end{array}$ & $\begin{array}{l}\text { Builder } \\
\text { of new house made } \\
\text { from reusable } \\
\text { materials }\end{array}$ & $\begin{array}{l}\text { Non-production } \\
\text { participants: } \\
\text {-buyers of new houses } \\
\text {-city authority } \\
\text {-environment } \\
\text { administration } \\
\text {-waste landfill owners } \\
\text {-owners of lands }\end{array}$ \\
\hline \multicolumn{4}{|c|}{$\begin{array}{l}\text { Common purposes } \\
\text { Purpose 1: decreasing quantity and size (square, volume) of non-legal waste landfills } \\
\text { Purpose 2: decreasing costs on utilization of building scrap }\end{array}$} \\
\hline \multicolumn{4}{|c|}{$\begin{array}{l}\text { Tasks for achieving common purposes: } \\
\text { Task 1: Find a place or issue, where reusable building materials could be used again in large } \\
\text { quantities }\end{array}$} \\
\hline
\end{tabular}

Table 3. KPI system for cluster of building materials scrap recycling.

\begin{tabular}{|l|l|}
\hline Cluster participant & \multicolumn{1}{c|}{ System of Key Performance Indicators } \\
\hline $\begin{array}{l}\text { Supplier } \\
\text { of building scrap } \\
\text { from demolition site }\end{array}$ & $\begin{array}{l}\text { KPI 1 Cost of utilization of building material scrap - legitimacy carrying } \\
\text { out and landfill } \\
\text { KPI 2 Cost of carrying out to non-legitimacy landfill }\end{array}$ \\
\hline $\begin{array}{l}\text { Recycler } \\
\text { of building scrap to } \\
\text { reusable building } \\
\text { materials }\end{array}$ & $\begin{array}{l}\text { KPI 3 Cost of recycling building material scrap to reusable products } \\
\text { KPI 4 Share from whole quantity of utilized building scrap, pushed to } \\
\text { reuse in new house building }\end{array}$ \\
\hline $\begin{array}{l}\text { Buyer } \\
\text { of new house made } \\
\text { from reusable } \\
\text { materials }\end{array}$ & $\begin{array}{l}\text { KPI 5 Cost of purchase reusable building materials } \\
\text { KPI 6 Cost of building new house or capacity from reusable building } \\
\text { materials }\end{array}$ \\
\hline $\begin{array}{l}\text { Non-production } \\
\text { participant: } \\
\text { city authority and } \\
\text { society }\end{array}$ & $\begin{array}{l}\text { KPI 7 Total quantity of utilized building materials scrap } \\
\text { KPI 8 Share from whole quantity of utilized building materials scrap, } \\
\text { pushed to reuse in new house building } \\
\text { KPI 9 Share from whole quantity of utilized building materials scrap, } \\
\text { pushed to legitimacy waste landfill } \\
\text { KPI 10 Share from whole quantity of utilized building materials scrap, } \\
\text { pushed to non-legitimacy waste landfill } \\
\text { KPI 11 Square size and increase of square size of non-legitimacy waste } \\
\text { landfill }\end{array}$ \\
\hline $\begin{array}{l}\text { Non-production } \\
\text { participant: } \\
\text { waste landfill owner }\end{array}$ & $\begin{array}{l}\text { KPI 12 Square size and increase of square size of non-legitimacy waste } \\
\text { landfill } \\
\text { KPI 13 Square size of non-suitable lands for agriculture, forestry and } \\
\text { living }\end{array}$ \\
\hline $\begin{array}{l}\text { Whole cluster as a } \\
\text { system }\end{array}$ & $\begin{array}{l}\text { KPI 14 Decreasing quantity and square size of non-legitimacy waste } \\
\text { landfills (interests of city administration, citizens) } \\
\text { KPI 15 Decreasing costs on utilization of building material scrap (interest } \\
\text { of demolition works contractors, real estate developers, builders, city } \\
\text { administration) }\end{array}$ \\
\hline
\end{tabular}




\section{Problem}

Problem of building scrap recycling cluster absence in Voronezh, and in whole Russia. This problem is a result of hope on large lands reserve, lack of technical and science proving of building scrap recycling necessity and divergence in purposes of building companies, waste landfills owners, and citizens.

From 2016 till 2020 year after demolition of tumbledown houses in the city, to operating legitimize waste landfills will be send not less 1 million tons of building scrap. This volume of scrap will fulfilled landfill so fast as at once. There are 1 million of mineral materials would be lost. Because of it 1 million of virgin materials have to be mined again. These materials at minimum could be use for filling foundation pits and another kind of pits [19, $20,21,22,23,24]$. In the table 4 is presented divergence of cluster participants purposes.

Table 4. Purposes' divergence of cluster participants.

\begin{tabular}{|l|l|}
\hline \multicolumn{1}{|c|}{ Participant } & \multicolumn{1}{c|}{ Purposes } \\
\hline Demolition works contractor & Minimum spend of time and money for demolition house \\
\hline Waste landfill owner & $\begin{array}{l}\text { Minimum costs on exploitation of waste landfill and its } \\
\text { lifetime extension }\end{array}$ \\
\hline Recycler of building materials scrap & Compensation costs on recycling \\
\hline Voronezh Technical State University & Engineering control under processes \\
\hline Building companies & $\begin{array}{l}\text { Minimal cost of building materials } \\
\text { Stable quality of building materials }\end{array}$ \\
\hline $\begin{array}{l}\text { Owners of raw virgin construction } \\
\text { materials deposits }\end{array}$ & Maximal benefit from deposit exploitation \\
\hline Consumer (citizens) & Good quality of house, minimal costs \\
\hline City administration & $\begin{array}{l}\text { Minimal wasting of lands } \\
\text { Support hygienic condition in the city } \\
\text { Support cost level on living houses } \\
\text { Support civilian legal order }\end{array}$ \\
\hline $\begin{array}{l}\text { Seller a reusable building materials } \\
\text { and products out from it }\end{array}$ & $\begin{array}{l}\text { Maximal benefit from activity } \\
\text { Stable income } \\
\text { Decrease a tax base }\end{array}$ \\
\hline $\begin{array}{l}\text { Companies - manufacturing building } \\
\text { materials }\end{array}$ & $\begin{array}{l}\text { Maximal benefit from activity } \\
\text { Stable income } \\
\text { Decrease tax base }\end{array}$ \\
\hline
\end{tabular}

\section{Problem solution model}

For solution problem it is need to compose its detailed description. It was chosen two kinds of problem's presentation. The first kind is organizational structure of cluster. The second kind is flow and capacity diagram of cluster structure. In the first kind of model is presented geographical location of system's parts, owners of parts and relations in the system. In this model we can see, that take part private companies, university, city administration. Geographically all participants are non concentrated. 


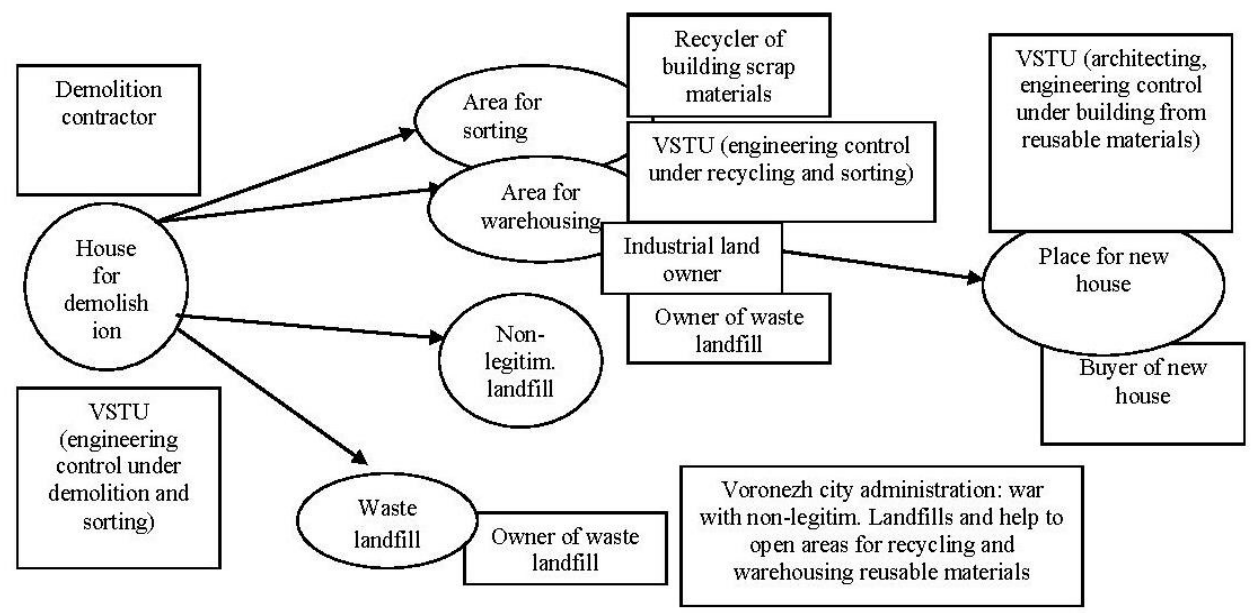

Fig. 1. Participant's distribution to roles in the cluster of building materials scrap recycling.

In the second model were presented volume of flows of materials from one part system to another part, and volume capacity of parts. For example, volume capacity of part 1 is 300 units, and by input in it flow with volume 10 units, we got fulfillment this part in 30 cycles. There are acting another rules of functioning this model:

1) By fulfillment part "Waste landfill" more than it's volume capacity, begins itself automatically renewing. By this cause, expenditures of citizens rise, and it decrease volume capacity of part "Buyers of new houses";

2) Volume capacity of part "Sorting and recycling of building scrap" shows square capacity of place of warehousing and sorting of recycling process of building materials scrap;

3) Throughput capacity of part "Sorting and recycling of building scrap" shows velocity of recycling incoming quantity of building scrap from demolished houses and another building processes;

4) Volume capacity of part "Buyers of new houses" could be increased due to increasing flows of scrap materials to part "Sorting and recycling of building scrap" and due to improving sell conditions to buyers.

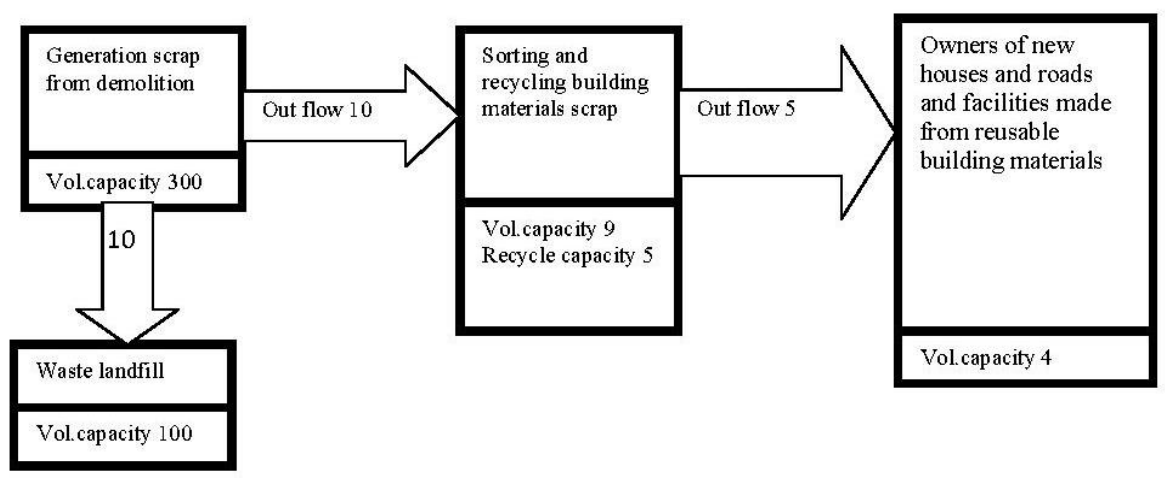

Fig. 2. Quantity characteristic of system of a building scrap generation, recycling and re-use into new houses.

Cause of cancel from using existed technologies of manufacturing reusable building materials from building scrap is prevailing economical interests above environment interests in modern society [7-12]. The second cause is possibility of using large reserve of national 
land squares. But current land reserves each year decrease more and more because of run rising of cities. Thus, legitimacy waste landfills increase in squares, and open in new places. New waste landfills come closer and closer to forests, agricultural and fields and living areas. It brings high risk of peoples' poisoning and epidemic, and risk of treat wild animals and birds.

\section{References}

1. P. Drucker, Management tasks in XXI century (Unity, Moscow, 2000)

2. D. Parmenter, Key Performance Indicators: Development, implementation and using decisive indicators (Olymp-business, Moscow, 2008)

3. A. Agarkov, R. Golov, Projecting and formation innovative industrial clusters (Dashkov and Co, Moscow, 2016)

4. P. Goswami, D.K. Banwet, K.K. Goswami, Procedia 189, 133-143 (2015)

5. J. Kádárová, M. Durkáčová, L. Kalafusová, Procedia - Social and Behavioral Sciences 143, 174-179 (2014)

6. C.D. Handson, A. Pimenta, P.D. Ball, Procedia CIRP 26, 677-682 (2015)

7. S. Zolotukhin, Science herald of Voronezh architectural-building university Series: High technologies. Ecology, 63-66 (2011)

8. S. Kolodyazhny, S. Zolotukhin, A. Abramenko, O. Kukina, A. Vyazov, A. Lobosok, V. Mylovanova, patent 2647521 Russian Federation, MПK E02D 27/01 (2006/01) (Voronezh State Technical University, 2017)

9. O. Artamonova, O. Kukina, M. Solokhin, International conference " Deformation and crushing of materials and nanomaterials" Dfmn, 638-640 (2013)

10. S.N. Zolotukhin, O.B. Kukina, A.A. Abramenko, E.A. Soloveva, E.A. Savenkova, IOP Conference Series: Earth and Environmental Science 90, 012088 (2017)

11. S. Zolotukhin, A. Abramenko, V. Mischenko, Voronezh, Finance, economy and strategy 12(137), 69 - 77 (2017)

12. O. Kukina, PhD Thesis, (VGASU, Voronezh, 2002)

13. G. Assefa, C. Ambler, Sustainable Cities and Society 28, 146-153 (2017)

14. J.Mehr, C. Vadenbo, B. Steubing, S. Hellweg, Resources, Conservation and Recycling 131, 181-191 (2018)

15. A K. Ali, R. Badinelli, Procedia Engineering 145, 164-171 (2016)

16. C. Gravinada, R. Miguel, A. Sattler, Resources, Conservation and Recycling 54-2, 104112 (2009)

17. K. Höglmeier, G. Weber-Blaschke, K. Richter, Resources, Conservation and Recycling 117-B, 304-314 (2017)

18. N. Dantata, A.Touran, J. Wang, Resources, Conservation and Recycling 44-1, 1-15 (2015)

19. L.A. Akanbi, L.O. Oyedele, O.O. Akinade, A.O. Ajayi, M.D. Delgado, M. Bilal, S.A. Bello, Resources, Conservation and Recycling 129, 175-186 (2018)

20. S. Huuhka, T. Kaasalainen, J.H. Hakanen, J. Lahdensivu, Resources, Conservation and Recycling 101, 105-121 (2015)

21. J. Charytonowicz, M. Skowroński, Procedia Manufacturing 3, 1633-1637 (2015) 
22. O.O. Akinade, L.O. Oyedele, M. Bilal, S.O. Ajayi, H.A. Owolabi, H.A. Alaka, S.A. Bello, Resources, Conservation and Recycling 105-A, 167-176 (2015)

23. B. Sanchez, C. Haas, Journal of Cleaner Production 183, 998-1010 (2018)

24. O.O. Akinade, L.O. Oyedele, S.O. Ajayi, M. Bilal, H.A. Alaka, H.A. Owolabi, S. A. Bello, B.E. Jaiyeoba, K.O. Kadiri, Waste Management 60, 3-13 (2017) 